\title{
REVIEW I Dangerous Mediations: Pop Music in a Philippine Prison Video
}

Áine Mangaoang

New York, NY: Bloomsbury, 2019

ISBN 9781501331534 (HB)

\author{
Monika E. Schoop \\ Leuphana University Lüneburg \\ monika.schoop@leuphana.de
}

In Dangerous Mediations: Pop Music in a Philippine Prison Video Áine Mangaoang examines the relationship between popular music, (social) media and power, placing the dance program of Cebu Provincial Detention and Rehabilitation Center (CPDRC) at heart of her analysis. Initiated by prison Warden Byron F. García, the program and its participants, the "Dancing Inmates of CPDRC", gained YouTube stardom in the late 2000s, most notably through their performance of Michael Jackson's "Thriller". The success of the performance videos on the social media platform subsequently turned the prison's dance program into one of Cebu's main tourist attractions. Employing an established methodological toolkit from musicology and ethnomusicology, Mangaoang breaks new ground by bringing together a wealth of perspectives on CPDRC's dance program, its use of popular music, and the performances and (re)mediations of "Thriller" in particular. In her analysis, the author goes beyond inquiring into the obvious YouTube stardom, and successfully unravels the complexities of the phenomenon. Following different lines of inquiry, the individual chapters "zigzag" (11) across diverse themes, from social media, (post)colonialism, music and punishment, to (re)mediation, hybridity and nostalgia; always highlighting their intersections with popular music. As a result, the book occasionally reads like a collection of individual articles. This, however, can be considered a strength when using the book as a teaching resource.

The multifaceted critical analysis of the program and its "dangerous mediations" makes the book a substantial contribution to the study of popular music in the Philippines, a field of research that has so far received only minor attention. It specifically constitutes a valuable contribution to research on music and social media in the Philippine context, a topic that remains heavily understudied with very

IASPM Journal vol.10 no.2 (2020) 
few exceptions (Castro 2010; Schoop 2017), despite the high prevalence of platforms such as Facebook and YouTube in the country. Two streams of inquiry are particularly intriguing: first the exploration of CPDRC's dance program in the context of postcolonial power relations and second its location in the history of detention.

In Chapter 2 Mangaoang makes visible how colonial legacies live on in the dance program, the performances and their (re)mediations. She uncovers how the success of CPDRC's "Thriller" is rooted in colonial histories and postcolonial discourses, connected to both the time of the Spanish (1565-1898) as well as USAmerican colonization (1898-1946) of the Philippines. She demonstrates how stereotypes of Filipinos as innately cheerful and musical people, dating back to the period of Spanish colonialization, are reflected in and have contributed to the success of the dance program; an association that is intensified through common perceptions of Cebu's vibrant cultural life, which resonate with the prevailing "musical-Philippine" (64) stereotype. The author further shows that the performance can be read as an extension of the colonial education established during the time of US colonization, privileging the English language and North American or so-called Western popular music. This inspection of imprisoned and postcolonial "others" dancing to a Western pop soundtrack makes the book a substantial contribution to musicological research on postcolonialism and nationalism in the Philippine context.

Chapter 4 reads CRDRC's program against the background of a broader history of detention. Mangaoang explores how the rehabilitation program draws on a variety of influences that can be located at different points in penal history. She shows how it on the one hand constitutes a return to a form of punishment as a public event focusing on the prisoner's body, a practice that can be found from Ancient Rome to the Middle Ages. She draws attention to the use of music as punishment and torture, before contextualizing the program in the shift to the modern prison system, focusing on the disciplining and rehabilitation of prisoners. Applying Michel Foucault's concept of "docile bodies" (1977 [1975]: 138), she shows how the prisoner's bodies are (made) obedient to choreographic instructions in the prison yard, and are subject to constant visual and auditory surveillance. Through this inquiry, Mangaoang successfully puts the Philippines on the map of the growing number of studies on music and detention.

Lastly, I would like to highlight two themes cross-cutting the book that merit attention. Through the nuanced inspection of the highly ambivalent nature of the rehabilitation program, Mangaoang uncovers a range of ethical problems and questions of representation. She raises awareness for the potential impact of the program and its "dangerous mediations" for the inmates, who become associated with their (alleged) crimes though the performance; a fact that is all the more problematic given that the prisoners at CPDRC are not yet convicted and awaiting trial. While conditions of imprisonment and physical fitness may have improved through the program, participation is likely to have a long-lasting negative effect on the lives of the dancers. Voluntary participation and informed consent to its potentially adverse consequences remain at best questionable.

The book also shows that inmates are constantly exposed to gazes that other them: the(post)colonial gaze, the tourist gaze, the panoptic gaze inside the prison, the gaze of the YouTube spectators. The gaze remains unidirectional. This is especially evident with regard to the performances' remediations on social media. While CPDRC's "Thriller" and other routines have gone viral, the dancers remain on the other side of the digital divide. Subject to the gaze of the YouTube audience, they have no access to, let alone control over, their representation. Forced to remain 
passive, their voices are silenced by the (Western) pop soundtrack. At this point a stronger focus on the literal voices of the inmates could have provided a valuable additional perspective. Mangaoang's decision to not include excerpts from her interviews with inmates, however, is understandable from an ethical perspective.

\section{References}

Castro, C. 2010. Subjectivity and Hybridity in the Age of Internet Media: The Musical Performances of Charice Pempegco and Arnel Pineda. Humanities Diliman 7 (1): 1-23.

Foucault, M. 1977 (1975). Discipline and Punish: The Birth of the Prison. Translated by Alan Sheridan. London: Penguin.

Schoop, M. E. 2017. Independent Music and Digital Technology in the Philippines. London and New York: Routledge. 